\title{
Regeneration patterns in a Calluna vulgaris heathland in the Cantabrian mountains (NW Spain): effects of burning, cutting and ploughing
}

\author{
Leonor Calvo *, R. Tarrega, E. Luis \\ Area de Ecología, Facultad de Biología, Universidad de León, 24071 León, Spain
}

Received 29 November 2000; received in revised form 6 December 2001; received in revised form 2 March 2002; accepted 12 March 2002

\begin{abstract}
Regeneration after experimental disturbances (burning, cutting and ploughing) was studied in a heathland dominated by Calluna vulgaris (L.) Hull located in NW Spain. Regeneration of $C$. vulgaris was better after burning and ploughing than after cutting. When cut, this species was replaced by another resprouting ericaceous species, Erica tetralix L. Calluna seedlings suffered high mortality in the third and fourth years after all treatments. Herbaceous species, which dominated during the first year of the secondary succession, were gradually replaced by woody species characteristic of that area from the sixth and seventh years after cutting and burning, and during the tenth year after ploughing. Multivariate analysis showed a clear separation between the different treatments, reflecting different responses in the community to different disturbances and partly reflecting the vegetation status before disturbance. (C) 2002 Éditions scientifiques et médicales Elsevier SAS. All rights reserved.
\end{abstract}

Keywords: Calluna heathland; Ericaceous species; Experimental disturbances; Structural parameters; Vegetative regeneration

\section{Introduction}

Published accounts show that at the end of the XVIIIth century the most widespread vegetation in the north of Germany, Denmark, England, Scotland, Ireland, most of Holland, the north of Belgium, France, Spain, the south of Sweden and western Norway was an anthropo-zoogenic Calluna heathland Gimingham and De Smidt. 1983: Rode 1999). Heathland is one of the principal cultural landscapes of the Atlantic regions of western Europe. Formerly, heaths covered several million hectares Webb_ 1998, but the present area has decreased considerably, mainly due to changes in management Diemont et al. 1996: Webb 1998) In addition to land use changes, increased atmospheric nitrogen deposition may affect heathlands Geil and Bohbink, 1993. De Smidt, 1995. Yesmin et al, 1996. Alonso and Hartley 1998: Power, 1998: Wehb, 1998. Strandherg and_Lohansson, 1999 and increase the need to intensify management; because probably higher nutrient levels, may result in higher Calluna productivity, inducing a

\footnotetext{
* Corresponding author. Tel.: +34-987-291567; fax: +34-987-291501.

E-mail address: deglcg@unileon.es (L. Calvo).
}

shorter life-span and causing early replacement of Calluna by grasses in the absence of intensified management $\mathrm{Di}$ Emont et al. 1996) Because of these losses and changes in land use, these heathlands are now considered to have a high potential for nature conservation throughout Europe.

In Spain, upland heathlands with C. vulgaris (L.) Hull occur in the Cantabrian mountains of northern Spain. Other shrub communities, including $C$. vulgaris, are present in the lowlands. However, C. vulgaris heathlands are best represented in these mountain areas. At present C. vulgaris heathlands do not cover more than $5 \%$ of the surface area in the Cantabrian Mountain range (Calvo, unpublished data). All of these areas were traditionally used during the summer for grazing by transhumant flocks of sheep and goats from the south of Spain and by flocks from neighbouring villages. Grazing was basically by sheep guided by a shepherd and, to a lesser extent, by cows and horses grazing alone. At present two changes can be observed: firstly, the number of cattle in the mountain passes has decreased. In 1832 there were 551,032 transhumant sheep in the Province of León and in 2000 there were only 10,166 (García, personal communication). This decrease is mainly due to modifications in the livestock subsidy policy. Secondly, the type of livestock grazing has changed; there has been an increase in 
the number of cows and horses in comparison with sheep and this has caused changes in vegetation physiognomy.

Thus, basic management in these areas has been by grazing, as used to occur in equivalent heathlands in the north and west of Europe Diemont et al.. 1996: Webb. 1998. These heaths have a long history of grazing associated with burning. This was used to extend the grazing area and improve forage, a similar management method to that used in heaths of other west European countries such as France, Germany, The Netherlands, Great Britain, Belgium, Sweden and Denmark Gimingham 1981. Gimingham and De Smidt, 1983; Hobhs et al, 1984) Another traditional human activity in heathland communities, much more widespread in lowland areas, is ploughing in order to transform them into temporarily arable land for growing cereals Degn, 2001. As time passed and agrarian policy changed, these farming areas were abandoned in the 1970s and this started a secondary succession process towards heath communities Calvo, 1993; Calvo et al. 1998) All these traditional management activities are in decline so heaths have recently begun to be considered marginal lands and some of these upland heathlands have been turned into forest plantations, as has occurred in some west and central European areas (Rode, 1999)

Due to the wide distribution of this kind of community and its importance to conservation (several moorland plant communities have been included in the European Union Habitats Directive), the aim of this paper is to analyse the regenerative response after several experimental disturbances: burning, cutting and ploughing, which represent the main impacts on the C. vulgaris heathlands in NW León Province (Spain). This study focused on changes in the botanical composition, diversity and reproductive strategies in the different phases of the succession following disturbance.

\section{Materials and methods}

The study area is situated in the San Isidro mountain pass (León, NW Spain) at an altitude of $1600 \mathrm{~m}$ and on a site with no appreciable slope; its UTM coordinates are 30TUN072695. From a geological viewpoint, the area is characterised by polygenic forms that constitute a complex lithology derived from Cantabrian Area Palaeozoic materials. They include mountain limestone, massive quartzite and slate with levels of sandstone, limestone and conglomerates. The study plots are situated on the last mentioned and represent an example of the main characteristics of this type of area. The soils are Ranker or humic cambisol LTGE. 1995. They are soils on desaturated parent rock with very limited soil development, which only shows an accumulation of litter on soil (L) that is assiduously colonised by mosses and lichens, and also by humified organic soil layer $(\mathrm{F}$ and $\mathrm{H})$. In general they are rich in humus and dark in colour. They are typical of mountain climates. The calcium carbonate contribution is limited to that originating in decomposition of organic material but, given the climatic characteristics, even this is rapidly washed away Requero and Porta, 1998). The analysis of the soil's organic horizon showed a very acidic $(\mathrm{pH}=3.9)$, with high organic matter content (27.07\% of dry weight), low concentrations of total nitrogen $(0.79 \%$ of dry weight) and available phosphorus (4.64 ppm).

Regarding its current climatic and vegetation characteristics, the area is part of the Eurosiberian Region and is included in the subalpine bioclimatic stage Rívas Martíned et al, 1987. The climate is typically continental, characterised by a lack of an arid period. If one occurs, it is shorter than two months and always occurs during the warm season. Mean annual temperature on the site is $5.5^{\circ} \mathrm{C}$. The length of winter in this area is very important because of its limiting effects on plant growth. The winter is cold, with a mean temperature of $-3.5{ }^{\circ} \mathrm{C}$ in the coldest month. Mean annual precipitation is $1319.5 \mathrm{~mm}$, but the distribution of rainfall is irregular throughout the year, decreasing significantly during the summer. These climatic characteristics are clearly representative of these highland heath communities. The period of biological activity is reduced to eight months or less.

The study area is occupied by a humid heath, dominated by $C$. vulgaris (mean cover $>75 \%$ ) and with Erica tetralix and Vaccinium myrtillus L. (mean cover $<10 \%$ ). None of these is over $50 \mathrm{~cm}$ in height and they form a cover of homogeneous appearance. Erica australis L. also occurs in the area (mean cover $<2 \%$ ). Herbaceous species are not very abundant and contribute little (Deschampsia flexuosa (L.) Trin and Nardus stricta L. with a mean cover below 4\%, and Juncus squarrosus L., Carex muricata L., Aira caryophyllea L., Festuca rubra L., Jasione montana L. and Potentilla erecta (L.) Rauschel with mean cover values around $1 \%$ ). The heathlands where the experimental treatments were carried out had historically been used as pasture. When livestock numbers fall, $C$. vulgaris cover percentages increase and it is able to colonise new suitable areas. It has remained so over time. This implies that these communities, dominated by $C$. vulgaris, were approximately 30 years old when the treatments were carried out. That is, $C$. vulgaris was in the degenerative age stage according to Watt (1947). Within the area uniformly occupied by heath, three $10 \mathrm{~m} \times 10 \mathrm{~m}$ plots were randomly selected. A corridor of $5 \mathrm{~m}$ was left between plots. Before the treatments were applied, a vegetation inventory was carried out in 100 samples of $1 \mathrm{~m}^{2}$, covering the whole plot surface. Percentage cover of all woody species was visually estimated in each sampling unit, whereas herbaceous species were considered as a whole because they represented a very low percentage of the total cover. The pre-treatment results (B0: original pre-burning situation, $\mathrm{C} 0$ : original pre-cutting situation, P0: original pre-ploughing situation) are presented as the mean cover of 100 samples (Table 1 ). Plot B was burned in summer 1986 in order to simulate the traditional burning 
activities in these areas. No aboveground biomass survived the burning but the depth of burning into the soil was probably small due to the high humidity in this area. In plot $\mathrm{C}$, all the woody aboveground biomass was cut to ground level (summer 1985) but we only removed the standing biomass and part of the litter. All the cut biomass was removed to estimate the contribution of woody species to the total dry weight Luis et al. 1989. Plot P was ploughed by mechanical means in summer 1986 (with a tractor, ploughing depth was $50 \mathrm{~cm}$ ). All the vegetation stumps were eliminated by this treatment in order to eliminate vegetative resprouting.

After the treatments, regeneration was so slow that we used five samples of $1 \mathrm{~m}^{2}$ in each plot, chosen at random in the first season of sampling and marked for subsequent monitoring. The pre-disturbance stand was homogeneous in terms of plant cover of the dominant species (Calluna was clearly dominant in the three plots, with percentage cover greater than 75\%). However, in this situation there was little difference in terms of E. tetralix cover, because in the C0 $(18.5 \%)$ the percentage of cover was higher than in the B0 $(0.8 \%)$ and the P0 (1.2\%). An area of $5 \mathrm{~m}^{2}$ was therefore considered large enough for sampling. The samples were recorded annually (from two to ten years after treatments), listing all the species present (herbaceous and woody), and evaluating their cover on a semi-quantitative scale (cover percentage value estimated visually). No sampling was carried out during the year immediately following treatments because recovery after burning and cutting was sparse, and after ploughing it was nil.

From the data obtained, the following parameters were analysed.

- The percentage cover contributed by the different life forms: annual herbaceous species, perennial herbaceous species and woody species.

- The global diversity in the plot ( $H^{\prime} \gamma$, gamma diversity), by means of the Shannon index Shannon and Weaver 1949).

$$
H^{\prime}=-\Sigma p_{i} \log _{2} p_{i}
$$

where, $p_{i}$ is the probability of finding species $i\left(S p_{i}\right.$ cover/total cover).

Diversity components were also determined: richness, i.e. number of species $(S)$, and evenness $H^{\prime} / H_{\text {max }}^{\prime}=H^{\prime} / \log _{2} S$ Pielow.1969.

- Spatial heterogeneity in each plot ( $H^{\prime} \beta$, beta diversity) was calculated by the Margalef formula Margalef 1972].

$$
H^{\prime} \beta=H^{\prime} \gamma-\frac{\Sigma H^{\prime} \alpha}{n}
$$

where $H^{\prime} \gamma$ is the total diversity in the plot, $H^{\prime} \alpha$ is the diversity of each inventory of that plot, $n$ is the number of samples (5).
- Correspondence analysis [Hill. 1984) (CA, statistical package CANOCO; Ter Braak_ 1991) was used to relate the effect of the experimental treatments to the vegetation response. Mean cover values in the five units for each year were used in this analysis.

- A two-way (treatment and time, repeated measure) ANOVA of percentage cover was used to compare the regeneration of the species (life forms and alpha diversity) in successive sets of samples of the same experimental treatment and also to compare the results from the different treatments. The significance of the results was tested with the Tukey test (Tukey. 1949).

Plant nomenclature follows Tutin et al. (1964-1980.

\section{3.. Results}

\subsection{Cover of main species}

Mean cover values of the most abundant species in the study area, before and after the experimental treatments, are shown in Table 1 . Before the treatments the stand of vegetation was very homogeneous with clear dominance of C. vulgaris. The main difference among the plots was in the amount of E. tetralix. This species had $18 \%$ cover in the cut plot in contrast to values of around $1 \%$ in the other two; in addition E. australis did not appear in the cut plot but was present in the other two, although levels were very low. As regards herbaceous species, the presence of relatively high values for D. flexuosa, N. stricta, F. rubra, and Carex muri$c a t a$, is of note in the original situation. Only some scarce tussocks of D. flexuosa and F. rubra appeared in the first year and they were not taken into account.

The dominant species in these heaths, $C$. vulgaris, regrew after the experimental treatments, by means of germination and vegetative resprouting after burning and cutting, but only by germination after ploughing. During the fourth year after burning and ploughing the cover of this species decreased, probably due to high seedling mortality. The other woody species present in the area, E. australis, reappeared after burning and ploughing in plots where it was previously present. This species regrows mainly through vegetative resprouting (from the stump) after burning and germination after ploughing. Erica tetralix developed slightly differently: it recovered easily after cutting, replacing $C$. vulgaris, whereas after burning and ploughing it only appeared after the sixth and eighth years, respectively. Vaccinium myrtillus increased after cutting and burning, exceeding its initial cover from the second year after the disturbances. The increase in the ploughed plot was slower but it also exceeded initial cover from the fourth year.

Among herbaceous species, A. caryophyllea L. showed high cover percentages after ploughing and in the first years after burning. Nardus stricta, P. erecta and J. squarrosus were abundant in the cut plot, whereas J. squarrosus was 
Table 1

Mean cover and standard deviation (in brackets) of the most abundant species in the original situation $(\mathrm{O})$ and in the subsequent years $(2,3, \ldots, 10)$ after the experimental treatments $($ burning $=\mathrm{B}$; cutting $=\mathrm{C}$; ploughing $=\mathrm{P}$ )

\begin{tabular}{|c|c|c|c|c|c|c|c|c|c|c|c|c|c|c|}
\hline & $\begin{array}{l}\text { Aira } \\
\text { Caryophyllea }\end{array}$ & $\begin{array}{l}\text { Calluna } \\
\text { vulgaris }\end{array}$ & $\begin{array}{l}\text { Carex } \\
\text { muricata }\end{array}$ & $\begin{array}{l}\text { Deschampsia } \\
\text { Flexuosa }\end{array}$ & $\begin{array}{l}\text { Erica } \\
\text { australis }\end{array}$ & $\begin{array}{l}\text { Erica } \\
\text { Tetralix }\end{array}$ & $\begin{array}{l}\text { Festuca } \\
\text { Rubra }\end{array}$ & $\begin{array}{l}\text { Hieracium } \\
\text { pilosella }\end{array}$ & $\begin{array}{l}\text { Jasione } \\
\text { montana }\end{array}$ & $\begin{array}{l}\text { Juncus } \\
\text { squarrosus }\end{array}$ & $\begin{array}{l}\text { Nardus } \\
\text { stricta }\end{array}$ & $\begin{array}{l}\text { Polygala } \\
\text { microphylla }\end{array}$ & $\begin{array}{l}\text { Potentilla } \\
\text { erecta }\end{array}$ & $\begin{array}{l}\text { Vaccinium } \\
\text { myrtillus }\end{array}$ \\
\hline & $\begin{array}{l}\text { Annual } \\
\text { Herb }\end{array}$ & $\begin{array}{l}\text { Woody } \\
\text { species }\end{array}$ & $\begin{array}{l}\text { Perennial } \\
\text { herb }\end{array}$ & $\begin{array}{l}\text { Perennial } \\
\text { Herb }\end{array}$ & $\begin{array}{l}\text { Woody } \\
\text { species }\end{array}$ & $\begin{array}{l}\text { Woody } \\
\text { Species }\end{array}$ & $\begin{array}{l}\text { Perennial } \\
\text { Herb }\end{array}$ & $\begin{array}{l}\text { Perennial } \\
\text { herb }\end{array}$ & Annual herb & $\begin{array}{l}\text { Perennial } \\
\text { herb }\end{array}$ & $\begin{array}{l}\text { Perennial } \\
\text { herb }\end{array}$ & $\begin{array}{l}\text { Woody } \\
\text { species }\end{array}$ & $\begin{array}{l}\text { Perennial } \\
\text { herb }\end{array}$ & $\begin{array}{l}\text { Woody } \\
\text { Species }\end{array}$ \\
\hline BO & $0.4(0.5)$ & $86.7(10.5)$ & $0.2(0.4)$ & $2.8(2.9)$ & $2.0(9.6)$ & $0.8(3.0)$ & $0.4(0.20)$ & - & $0.2(0.4)$ & - & $2.8(4.2)$ & $0.2(0.4)$ & $0.2(0.4)$ & $2.4(1.5)$ \\
\hline B2 & & $13.3(12.3)$ & $0.2(0.4)$ & $12.0(13.4)$ & $0.4(0.9)$ & & $3.6(3.9)$ & $0.2(0.4)$ & & & & $1.2(0.4)$ & $0.4(0.9)$ & $8.6(3.5)$ \\
\hline B3 & $39.0(15.2)$ & $15.0(5.0)$ & $0.6(0.5)$ & $8.6(6.5)$ & $0.6(0.9)$ & & $11.0(4.2)$ & $1.0(2.2)$ & $0.4(0.5)$ & & $3.2(4.3)$ & $0.8(1.3)$ & $2.0(2.7)$ & $16.0(6.5)$ \\
\hline B4 & $17.0(8.4)$ & $0.2(0.4)$ & $2.2(2.2)$ & $3.2(3.4)$ & & & $12.2(8.1)$ & $0.2(0.4)$ & $1.2(1.6)$ & & $2.6(2.8)$ & $1.4(0.5)$ & $4.0(4.7)$ & $16.0(2.2)$ \\
\hline B5 & $8.0(4.5)$ & $0.8(1.3)$ & $1.6(1.3)$ & $0.2(0.4)$ & & & $15.6(6.1)$ & $1.0(1.2)$ & $1.2(1.3)$ & & $8.2(4.1)$ & $0.4(0.9)$ & $4.0(4.2)$ & $14.2(10.6)$ \\
\hline B6 & $8.2(4.7)$ & $4.8(3.3)$ & $1.2(2.2)$ & & $0.2(0.4)$ & $1.0(2.2)$ & $8.6(2.19)$ & $1.0(1.4)$ & $2.8(3.1)$ & & $3.8(1.1)$ & $2.2(0.8)$ & $1.8(2.05)$ & $30.0(19.2)$ \\
\hline B7 & $8.4(4.3)$ & $5.6(2.6)$ & $1.8(2.2)$ & $1.2(2.2)$ & & & $13.6(5.9)$ & $1.6(2.3)$ & $3.6(2.2)$ & & $9.2(4.3)$ & $1.4(0.9)$ & $5.2(6.9)$ & 25.0 (16.6) \\
\hline B8 & $10.0(3.4)$ & $16.6(7.3)$ & $0.8(1.2)$ & $0.6(1.3)$ & & $4.0(8.9)$ & $8.6(2.2)$ & & $3.4(1.2)$ & & $9.6(6.2)$ & $1.6(2.3)$ & $3.0(4.5)$ & $33.0(13.5)$ \\
\hline B9 & $7.0(4.9)$ & $15.0(10.6)$ & $1.2(1.6)$ & $2.8(2.2)$ & $1.6(3.6)$ & $3.6(6.5)$ & $7.6(4.9)$ & $3.0(4.5)$ & $2.0(1.7)$ & & $12.2(8.1)$ & $0.2(0.4)$ & $4.2(4.5)$ & $16.0(8.9)$ \\
\hline B10 & $6.4(4.2)$ & $22.0(16.8)$ & 2.4 (1.9) & $2.6(2.5)$ & $1.2(1.6)$ & & $8.0(2.7)$ & $3.0(1.9)$ & $3.2(2.1)$ & & $12.0(5.7)$ & $3.8(2.4)$ & $8.0(5.7)$ & $19.6(14.9)$ \\
\hline $\mathrm{CO}$ & $0.2(0.4)$ & $75.2(12.6)$ & $0.4(0.2)$ & $0.6(0.8)$ & - & $18.5(11.0)$ & $0.6(1.3)$ & - & - & $1.2(1.3)$ & $4.2(5.1)$ & - & $0.6(0.9)$ & $0.5(1.0)$ \\
\hline $\mathrm{C} 2$ & $1.0(1.4)$ & $0.4(0.5)$ & $0.2(0.4)$ & $2.0(3.4)$ & & $9.2(10.5)$ & $6.0(4.7)$ & & $1.6(3.6)$ & $1.2(2.2)$ & $23.0(14.4)$ & & $3.4(3.9)$ & $7.6(4.7)$ \\
\hline $\mathrm{C} 3$ & & $1.4(0.9)$ & $0.8(1.3)$ & $0.2(0.4)$ & & $17.2(14.5)$ & $9.6(8.2)$ & & $2.4(4.3)$ & & $21.0(6.5)$ & & $3.2(3.4)$ & $4.4(2.5)$ \\
\hline $\mathrm{C} 4$ & $0.6(0.9)$ & $7.2(4.1)$ & $2.4(4.3)$ & & & $32.0(18.2)$ & $7.4(3.4)$ & & $1.8(2.2)$ & $2.0(4.5)$ & $33.0(7.6)$ & $0.2(0.5)$ & $5.2(2.8)$ & $6.6(2.3)$ \\
\hline C5 & $3.2(3.3)$ & $2.8(4.2)$ & $1.4(1.5)$ & $1.0(2.2)$ & & $25.0(22.4)$ & $23.8(19.3)$ & & $1.6(2.3)$ & & $19.0(14.8)$ & $0.2(0.4)$ & $4.4(3.8)$ & $18.0(15.6)$ \\
\hline C6 & $0.4(0.5)$ & $0.8(0.4)$ & $1.6(2.3)$ & & & $26.8(28.3)$ & $5.2(6.4)$ & & $0.2(0.4)$ & $2.2(2.2)$ & $39.0(21.0)$ & & $5.8(3.4)$ & 13.8 (12.6) \\
\hline C7 & $0.2(0.4)$ & $3.8(3.2)$ & $2.2(2.2)$ & $0.8(0.8)$ & & $45.6(26.1)$ & $2.0(2.0)$ & & $2.2(2.2)$ & $5.0(8.7)$ & $11.2(3.6)$ & $0.6(1.3)$ & $6.0(3.7)$ & $13.0(5.7)$ \\
\hline $\mathrm{C} 8$ & $1.6(2.3)$ & $6.6(2.3)$ & $1.0(1.4)$ & $0.2(0.4)$ & & $36.0(29)$ & $16.0(27.3)$ & & $2.0(2.1)$ & $2.6(3.7)$ & $20.0(9.3)$ & $0.6(1.3)$ & $4.8(3.4)$ & $12.2(3.8)$ \\
\hline C9 & $3.0(4.5))$ & $7(10.9)$ & $4.0(8.9)$ & $0.6(1.3)$ & & $68.0(30.5)$ & $6.0(6.5)$ & & & & $17.0(5.7)$ & $1.6(2.3)$ & $9.0(10.2)$ & $9.0(4.2)$ \\
\hline $\mathrm{C} 10$ & $2.2(3.5)$ & $10.0(5.0)$ & 0.4 & & & $44.2(35.3)$ & $2.6(2.5)$ & & $2.6(2.2)$ & $16.0(14.7)$ & $28.6(26.5)$ & & $4.8(3.3)$ & $5.8(2.2)$ \\
\hline PO & $1.2(1.4)$ & $86.5(14.4)$ & $1.0(4.5)$ & $3.2(2.1)$ & $1.3(7.2)$ & - & $0.2(0.4)$ & - & $0.2(0.4)$ & - & $1.2(1.9)$ & - & - & $2.6(1.7)$ \\
\hline P2 & & $1.2(2.2)$ & & $2.6(1.7)$ & & & & $0.4(0.6)$ & & & & & & $0.8((0.5)$ \\
\hline $\mathrm{P} 3$ & $47.0(15.6)$ & $2.4(4.3)$ & $0.2(0.5)$ & $15.2(13.8)$ & $0.2(0.4)$ & & $1.0(2.2)$ & & & & & & & $1.4(2.1)$ \\
\hline P4 & $40.0(11.7)$ & & & $4.6(6.1)$ & $0.2(0.4)$ & & $2.4(4.3)$ & & $0.2(0.4)$ & & $1.0(2.2)$ & & & $4.8(3.4)$ \\
\hline P5 & $54.0(10.8)$ & $1.6(1.9)$ & $0.6(1.3)$ & & $0.2(0.4)$ & & $4.2(6.3)$ & & $0.4(0.5)$ & $0.6(1.3)$ & $2.2(3.5)$ & & $0.2(0.4)$ & $3.8(2.8)$ \\
\hline P6 & $45.0(10.0)$ & $4.2(3.6)$ & $0.6(1.3)$ & $2.0(2.7)$ & $0.6(1.3)$ & & $4.2(3.6)$ & & $0.2(0.4)$ & $0.4(0.9)$ & $3.0(4.5)$ & & $0.4(0.9)$ & $5.8(3.1)$ \\
\hline P7 & $62.0(21.9)$ & $8.2(2.5)$ & $0.6(0.9)$ & & $1.0(2.2)$ & & $6.0(3.1)$ & & $1.2(2.2)$ & & $3.8(3.9)$ & & $0.8(1.3)$ & $4.8(2.0)$ \\
\hline P8 & $59.0(15.6)$ & $8.2(2.5)$ & & & & $2.0(2.7)$ & $3.8(2.9)$ & & $1.6(2.3)$ & $1.0(2.2)$ & $3.6(5.0)$ & & $1.6(2.3)$ & $4.8(2.0)$ \\
\hline P9 & 36.0 (12.9) & $16.6(10.1)$ & $0.4(0.9)$ & & $3.6(6.5)$ & & $6.2(3.9)$ & $0.2(0.4)$ & $2.2(3.3)$ & & $3.0(4.5)$ & & & $4.4(2.6)$ \\
\hline P10 & $14.0(9.6)$ & $36.0(9.6)$ & $1.2(1.6)$ & $3.6(2.2)$ & & $0.6(1.3)$ & $4.6(3.6)$ & $0.4(0.8)$ & $2.6(2.5)$ & & $5.2(6.4)$ & $0.6(1.3)$ & $0.6(1.3)$ & $9.2(3.7)$ \\
\hline
\end{tabular}


absent after burning and only sporadic in the ploughed area. Nardus stricta appeared sparsely after burning and ploughing.

\subsection{Life forms}

Examination of the percentage cover of species grouped according to three life form categories (Fig. 1) indicates that, after burning, there was a predominance of perennial herbaceous species during the first five years, except for the third, when A. caryophyllea (an annual) showed a high cover value. Cover values of perennial herbaceous species suffered small oscillations, throughout the study period, but these were not significant. Annual herbaceous species peaked during the third year after burning, with the cover values for this year being significantly different from the rest $(P<0.05)$. Thereafter, cover values of annuals decreased because they were replaced by perennial species. Woody species increased their cover during the first three years, due to $C$. vulgaris cover, although there was a decrease in the fourth year. Increasing cover values during the first six years showed significant oscillations $(P<0.05)$; subsequently the differences for woody species were not significant.

Perennial herbaceous species were clearly predominant after the cutting treatment. Differences in the cover values between the years were not significant. From the seventh year onwards woody species, mainly E. tetralix, became predominant. Annual herbaceous species showed low cover values, never higher than $5 \%$. Their cover values in the original stand were also low.

The recovery of the plant community after ploughing started during the second year with a dominance of perennial herbaceous species. However, after that time and until the ninth year annual herbaceous species, mainly A. caryophyllea, were dominant. Their cover values varied significantly $(P<0.05)$ during the study period, decreasing from the ninth year onwards. Perennial herbaceous species did not show high cover values and the differences were not significant over the study period. The cover value for woody species was very low at the beginning, increasing significantly in the ninth year compared with the other plots.

The cover of woody, annual and perennial herbaceous species present significant differences $(P<0.05)$ between ploughing and the other two treatments until the ninth year. However, differences in life form cover between treatments disappeared 10 years after disturbance.

\subsection{Structural parameters}

Species richness values (Fig. 2a) were slightly higher in the burnt plot than in the other two, except for the second year after the treatment. There were fewer species regrowing during the six first years following the ploughing treatment, which represented a more drastic alteration of the vegetation. From this time onwards, richness values are

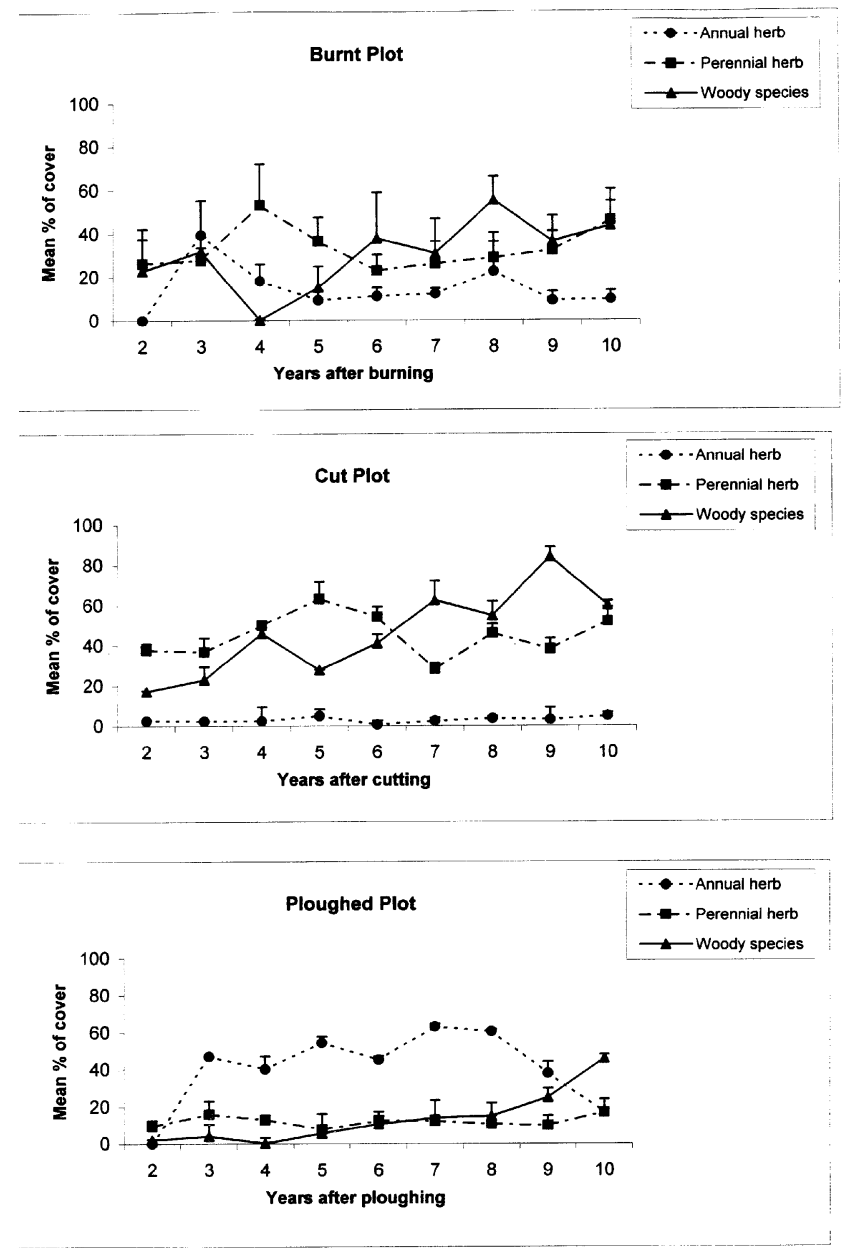

Fig. 1. Mean percentage cover of life forms (annual herbaceous species, perennial herbaceous species and woody species) and standard error in each treatment.

similar to those for the other two treatments. The specific richness values 10 years after treatment show practically the same tendencies, that is the burned plot had the greatest richness. However, the total richness values in the three plots after 10 years are greater than those in the original situation.

During the second year after treatments, evenness values in the three plots were similar due to slow recovery and the lack of a dominant species (Fig. 2b). These values are relatively high and very similar throughout the study period, both after burning and cutting. However, after ploughing there was a great dominance of annual species, mainly A. caryophyllea, which led to lower evenness values. In general, evenness values in the three plots (in the time) after the treatments are higher than those in the original situation. This is due to the dominance of the woody species in the original situation, an aspect which starts to be observed after 10 years' study.

Gamma diversity values (Fig. 2c) were higher after burning and increased slightly through time due to the rise in the number of species and the relatively high evenness. Changes after cutting followed a similar pattern. However, 
a)

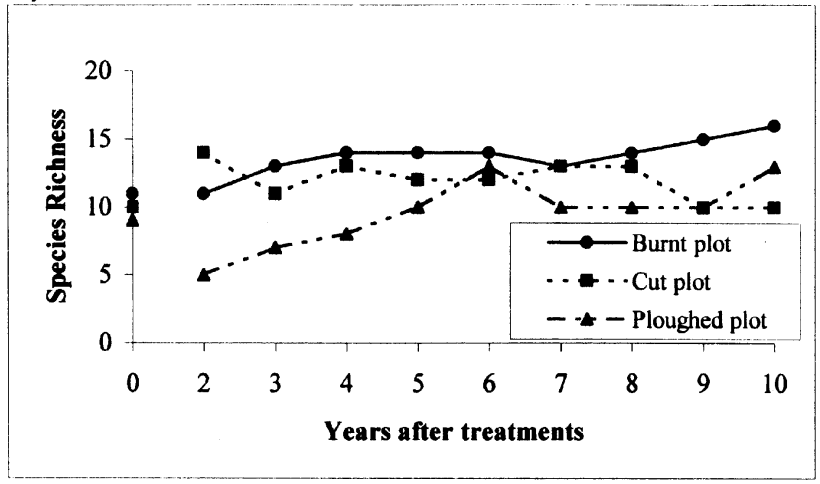

c)

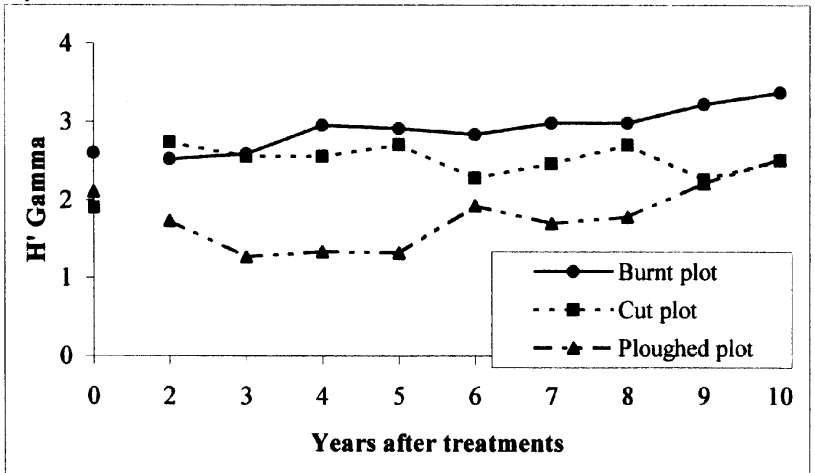

b)

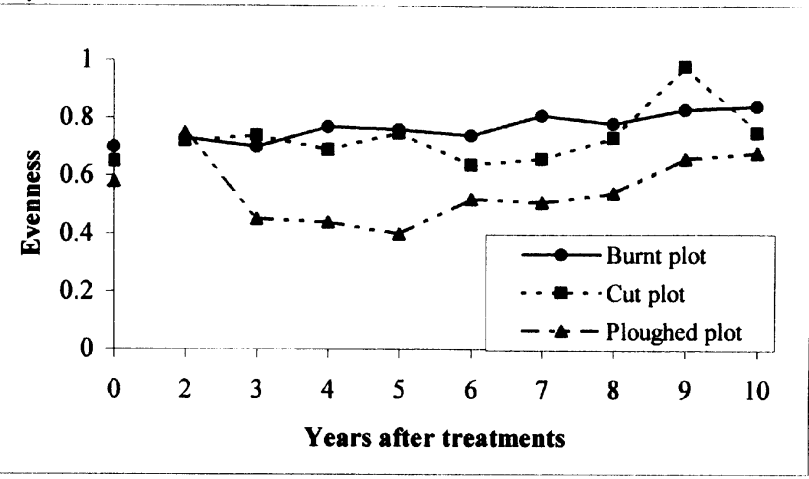

d)

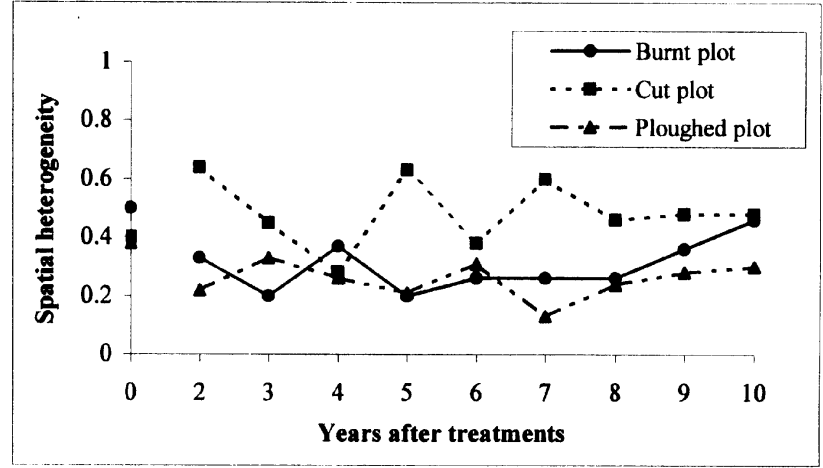

Fig. 2. Values over time of (a) species richness, (b) evenness, (c) Gamma diversity and (d) spatial heterogeneity in the plots. $0=$ original situation; $1,2,3, \ldots, 10$ $=$ years after treatments.

during the ninth year, gamma diversity decreased due to the strong dominance of E. tetralix and N. stricta. Diversity values were lower in the ploughed plot due to the lower species richness and the strong dominance of A. caryophyllea. During the last years of the study, the ploughed plot did not show any differences from the cut plot but both differed from the burnt plot. During the first six years differences were significant between ploughing and the other treatments $(P<0.05)$. The behaviour patterns 10 years after the treatments resemble what occurs in the original situation, the burned plot shows the greatest diversity.

Spatial heterogeneity values (Fig. 2d) showed oscillations without any clear trend over time. There was a large oscillation in the heterogeneity values in the cut plot during the first years after cutting. Oscillations decline after eight years. Calluna vulgaris, which originally occupied most of the cut plot, was replaced by E. tetralix, and this was reflected in the heterogeneity values. Ploughing led to a lower spatial heterogeneity (on the scale considered here) in the vegetation distribution because regeneration started in a relatively homogeneous way.

\subsection{Multivariate analysis}

Correspondence analysis (CA) (Fig. 3a, b) of the mean cover values for each species in each plot in each of the years of recording showed a separation between the values obtained for the samples in the different plots. Axis I of Fig. $3 \mathrm{~b}$ (which accounted for $54.9 \%$ of total variance) differentiated between burning and ploughing treatments in the positive section against cutting in the negative part. This division was due to the presence of the following species in the cut plot with high cover values: E. tetralix, N. stricta, $J$ squarrosus and P. erecta. Axis II of Fig. 3b (36.4\% of total variance) allowed us to differentiate the first samplings from the burned and ploughed plots and the rest due to the high cover of Agrostis capillaris L., D. flexuosa and E. australis. Aira caryophyllea segregated samplings from the ploughed plot. However, during the 10th year there were no differences between burning and ploughing treatments.

\section{Discussion}

Knowledge of the response of Calluna heathland to the different treatments representing the main human impacts is a basic requirement for defining adequate management. Calluna vulgaris, the dominant species in these areas, recovers slowly during the 10 year study after the experimental treatments in comparison with the original values. This may be due primarily to the fact that $C$. vulgaris was approximately 30 years old in the original situation and is considered old, which lowers its capacity to resprout. On the other hand, the acidity of the soil may have a negative 

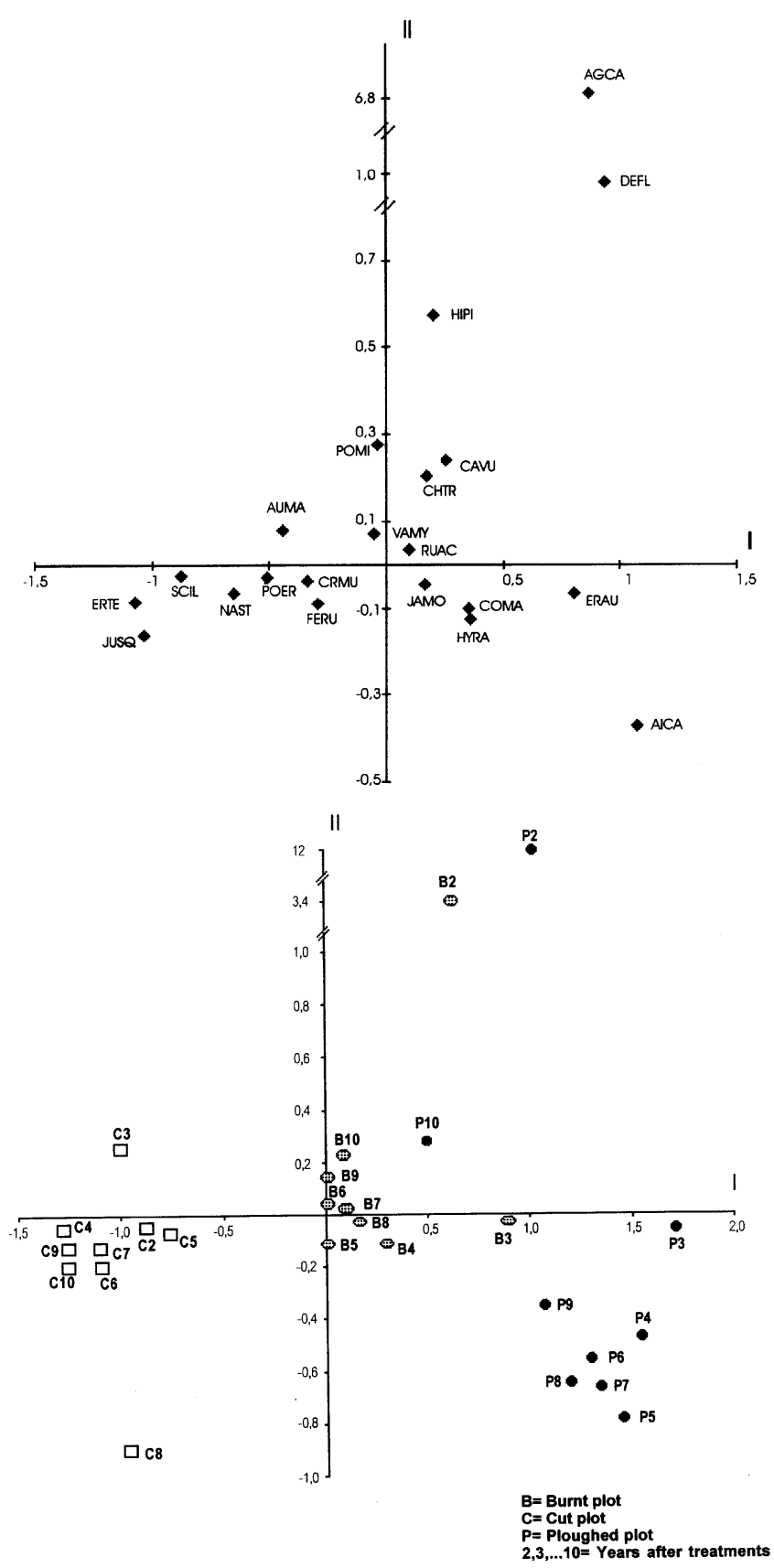

Fig. 3. (a) Correspondence analysis of cover values of vegetation (ordination of species). (Abbreviations: AGCA: Agrostis capillaris; AICA: Aira caryophyllea; AVMA: Avenula marginata; CAVU: Calluna vulgaris; CRMU: Carex muricata; CHTR: Chamaespartium tridentatum; DEFL: Deschampsia flexuosa; ERAU: Erica australis; ERTE: Erica tetralix; FERU: Festuca rubra; HIPI: Hieracium pilosella; HYRA: Hypochoeris radicata; JAMO: Jasione montana; JUSQ: Juncus squarrosus; NAST: Nardus stricta; POMI: Polygala microphylla; PTER: Potentilla erecta; RUAC: Rumex acetosella; SCIL: Scilla sp. VAMY: Vaccinium myrtillus.). (b) Correspondence analysis of cover values of vegetation (Ordination of mean cover values from 5 samples in each plot, in each year after treatments).

impact on the germination of its seeds Diemont, 1990) However, in the burned plot a good initial response was observed, probably due to germination being stimulated by the increase in temperature (Webb.1998 and probably by the increase in the soil pH after fire (Marcos et al. 1998) The favourable effects of fire on germination have been mentioned by several authors (Mallik and Gimingham 1985;González-Rabanal and Calsal, 1995: Valbuena et al. 2000. In this burned plot, $C$. vulgaris cover decreases after the fourth year, mainly due to seedling mortality because of the high number of days (a mean of approximately 10 days per month during winter) on which this species was under snow and the possible secondary effects caused by this, like fungal infections. After cutting, germination of C. vulgaris was not stimulated and vegetative resprouting had the same problem as in the burned plot. For this reason it has a low percentage cover throughout the study period. In the ploughed plot, the germination response was very low. However, according to Degn (2001, in ploughing areas Calluna vegetation takes about 13 years to increase significantly.

Vegetation dynamics in heathlands seem to depend on the interaction between the species attributes and the climatic conditions in the area Clement and Touffet, 1981. Several studies state that $C$. vulgaris is slow to regenerate because its vegetative sprouting rates are not particularly high when the plants are too old and neither are the seed germination rates (Helsper and Klerken, 1984; Pons 1989) Germination in C. vulgaris is affected by moisture supply, $\mathrm{pH}$, etc., and so may be low in some field situations Diemont.1990. If the soil moisture content is high enough for seedling emergence, seed density in the soil as well as $\mathrm{pH}$ may also affect seedling emergence. Under optimal moisture conditions in the laboratory, a lower soil pH (as in these areas) suppressed seedling emergence of Calluna and consequently affected the assessment of the seed bank of this shrub (Diemont, 1990)

The slow regeneration of $C$. vulgaris allows other woody species to spread, mainly those species like E. tetralix, whose germination and resprouting are not so dependent on external factors Bruggink. 1993). In the cut plot C. vulgaris does not sprout because it is old and, in addition, it does not germinate well because of competition from herbaceous species present in the area and the highly acidic edaphic conditions. Thus in the cut plot E. tetralix, which already had greater cover in this plot than in the other two, becomes the dominant woody species after treatment. However, it is difficult to determine to what extent its great proliferation is due to initial differences or due to the effect of cutting, or to both. In the other two plots, E. tetralix did not reappear until six years after burning and eight after ploughing. In both cases, cover was very low in the original situation. Bannis $\operatorname{ter}(1964)$ did not observe germination of this species in the first few years after burning either. Another woody species which increased in cover after all the treatments, in comparison with the initial stand was V. myrtillus, with higher values in the burned plot, where this woody species was dominant from the fourth year. Vaccinium myrtillus has a great vegetative regeneration capacity, stands shade well, and is easily able to live under $C$. vulgaris, thus protecting 
itself from herbivores CAlonso. 1994. These differences in the response of the species present in the study area led to the small differences between plots, a reflection of spatial microheterogeneity in an area that was homogeneous on a larger scale due to the clear dominance of C. vulgaris, increasing considerably after the treatments.

On the other hand, during the first years after all treatments there was a clear dominance of herbaceous species (i.e., N. stricta in the cut plot, A. caryophyllea in the ploughed plot), which concurs with what was observed by other authors in the same type of community (Mallik and Giminoham 1983. Mallik 1986. Clement and Touffet 1990: Forgeard 1990: Deon. 2001 and in other shrub ecosystems Casal, 1982, 1987; Kruger, 1984; Calvo et al. 1992. Competition with woody species was eliminated and favourable environmental conditions such as increased light availability encouraged their development. The rapid recovery of perennial species probably resulted in low cover values for annual species, especially in the cut plot. However, in the ploughed plot, herbaceous annuals seem to have an advantage over the rest as there is no possibility of vegetative resprouting. Woody species tend to be dominant in most shrub communities from the third year after disturbance Forgeard 1990. However, this was not observed in the plots studied until the seventh year after cutting and later after the other two treatments.

The ploughed plot had the lowest diversity values because of both the lower species richness and low uniformity, due in this case to the dominance of a herbaceous annual, A. caryophyllea. It could be considered that ploughing was the most drastic treatment because it destroyed all the vegetation and altered the structure of the soil. Therefore, regeneration started a year later than in the other two treatments and the different regeneration phases developed more slowly, as reflected by lower richness and diversity values. The possibility of vegetative sprouting, which is stimulated by cutting and burning in species like V. myrtillus and E. tetralix, together with the lack of disturbance of the soil structure, resulted in better initial recovery in the burnt and cut plots than in the ploughed one. Diemont et al 1996 point out that vegetative regeneration is the main recovery mechanism in upland heathlands with their greater humidity. This contrasts with some lowland heath areas where recovery from seedlings is predominant. In contrast, resprouting is the main plant response after cutting and after flash fires. This is also likely to have been the dominant mechanism in the cut and burned plots in the case of both the woody species (E. tetralix, E. australis and V. myrtillus) and the herbaceous perennials (N. stricta, J. squarrosus, F. rubra). Hester et al_(1991) state that V. myrtillus uses vegetative resprouting as its main recovery mechanism and takes advantage of the decline in $C$. vulgaris to increase its cover. However, the low vigour of $C$. vulgaris and its high mortality rate in the burned plot lead us to think that it came mainly from seed and did not have time to develop a root system which would allow survival under unfavourable conditions. This coincides with the results of Vera and Obeso (1995), who did not find any resprouting of C. vulgaris after the fire.

Regardless of the disturbance, during the 10th year there were no differences in the degree of recovery. The effect of cows and horses grazing in the experimental area probably interfered with the speed of regeneration after all treatments. Analysis of the changes in the values of the structural parameters shows that those of the original situation were not attained in any case. This is due to the fact that recovery of these Calluna heathlands is probably at the building stage, and the optimum, according to Giminghan (1981), of the building stage appears after 15 years. After that period, it enters a degenerative stage and thus would attain the initial values of the structural parameters. Oscillations in the values of the structural parameters suggest that full structural stabilisation of the community has not yet been attained. When this process is compared with what happens in E. australis heathlands in lower areas Calvo et al. 1998 it is obvious that regeneration in Calluna heathlands is slower, due to a shorter growing season in the mountains.

Over time, percentage values for life forms and structural parameters indicate a reduction in differences between the three plots. However, the differences in specific composition remained in the 10th year, above all in the cut plot, where E. tetralix was still dominant. Calluna vulgaris began to dominate in the other two plots. In addition, a tendency towards increase $C$. vulgaris and a decrease in E. tetralix in the cut plot became apparent. Consequently, it is not clear whether the initial conditions of Calluna dominance will be regained in all the plots, or whether in contrast, the differences will be maintained. It is necessary to continue the study of this experiment in order to attain the degenerative stage after 15 years and to establish later changes in the vegetation composition.

It seems clear that cutting does not appear to be the best treatment for preserving Calluna communities which are probably more than 30 years old in the studied area. Nor do burning or ploughing appear to be suitable treatments. Probably, if these perturbations occur in heathlands in 10- or 15-year cycles, C. vulgaris be able to keep dominant according with the results obtained in other similar ecosystems Gimingham, 1981:Diemont et al, 1996. The change in farming practices, with (a) large flocks of sheep and goats being replaced by a lower stocking rate of cows and horses in very localised areas, and (b) the absence of disturbances associated with farming use (like burning), seems to be the main causes of the increase in the extent of this vegetation. However, it is too soon to state with any certainty whether these heathland communities will be sustainable in the longer term. Probably should be interventions by management such as burning every 10 or 15 years.

As shown in the plots studied, small differences in cover as regards epigean vegetation can be magnified as a result of management differences. Knowledge of these aspects is basic and fundamental for the correct administration and 
conservation of these Calluna heathlands, which are at present included among the Protected Natural Areas. The type of intervention will have to be very different depending on whether homogeneous communities with a clear Calluna dominance or a mosaic of more heterogeneous formations are to be favoured.

\section{Acknowledgements}

We wish to thank to Althea Davies from Stirling University for helping us to revise the article.

\section{References}

Alonso, I., 1994. Estudio ecológico y valoración de un sistema pastoral de la montaña de León. Ph.D. Thesis. University of León, Spain.

Alonso, I., Hartley, S.E., 1998. Effects of nutrient supply, light availability and herbivory on the growth of heather and three competing grass species. Plant Ecol. 137, 203-212.

Bannister, P., 1964. The water relations of certain heath plants with reference to ecological amplitude. III Experimental studies and general conclusions. J. Ecol. 52, 499-509.

Bruggink, M., 1993. Seed bank, germination, and establishment of ericaceous and gramineous species in heathlands. In: Aerts, R., Heil, G.W (Eds.), Heathlands: Patterns and Processes in a Changing Environment, Geobotany, 20. Kluwer Academic Publishers, Dordrecht, pp. $153-180$.

Calvo, L., 1993. Regeneración vegetal en comunidades de Quercus pyrenaica Willd. después de incendios forestales. Análisis especial de comunidades de matorral. Ph.D. Thesis. University of León, Spain.

Calvo, L., Tárrega, R., Luis, E., 1992. The effect of human factors (cutting, burning and uprooting) on experimental heathland plots. Pirineos 140, $15-27$.

Calvo, L., Tárrega, R., Luis, E., 1998. Space-time distribution patterns of Erica australis L. subsp aragonensis (Willk) after experimental burning, cutting and ploughing. Plant ecology 137, 1-12.

Casal, M., 1982. Sucesión secundaria en vegetación del matorral de Galicia tras dos tipos de perturbaciones: incendios y rozas. Ph.D. Thesis, University of Sevilla, Spain.

Casal, M., 1987. Post-fire dynamics of shrublands dominated by Papilionacea plants. Influence of fire on the stability of Mediterranean forest ecosystems. Ecol. Med. XIII, 87-98.

Clement, B., Touffet, J., 1981. Vegetation dynamics in Brittany heathlands after fire. Vegetatio 46, 157-166.

Clement, B., Touffet, J., 1990. Plant strategies and secondary succession on Brittany heathlands after severe fires. J. Veg. Sci. 1, 195-202.

Degn, H.J., 2001. Succession from farmland to heathland: a case for conservation of nature and historic farming methods. Biol. Conserv. 97, 319-330

De Smidt, J.T., 1995. The imminent destruction of northwest European heaths due to atmospheric nitrogen deposition. In: Thompson, D.B.A., Hester, A., User, M.B (Eds.), Heaths and Moorlands. Cultural Landscapes, SNH, Edinburgh. pp. 206-217.

Diemont, W.H., 1990. Seedling emergence after sod cutting in grass heath. J. Veg. Sci. 1, 129-132.

Diemont, W.H., Webb, N., Degn, H.J., 1996. Pan European view on heathland conservation. Proceedings of National Heathland Conference, English Nature, Peterborough, UK.

Forgeard, F., 1990. Development, growth and species richness on Brittany heathlands after fire. Acta Oecolog. 11, 191-213.
Gimingham, C.H., 1981. Conservation of heathlands. In: Specht, R.L (Ed.), Ecosystems of the World 9b, Heathlands and Related Shrublands. Elsevier Science, Publ. Amsterdam, pp. 249-259.

Gimingham, C.H., De Smidt, J.T., 1983. Heaths as natural and semi-natural vegetation. In: Holzner, W., Werger, M.J.A., Ikusima, I (Eds.), Man's Impact on Vegetation. Dr W. Junk Publishers, The Hague, pp. 185-199.

González-Rabanal, F., Calsal, M., 1995. Effect of high temperatures and ash on germination of ten species from gorse shrubland. Vegetatio 116, 123-131.

Heil, G.W., Bobbink, R., 1993. Impact of atmospheric nitrogen deposition on dry heathlands. A stochastic model simulating competition between Calluna vulgaris and two grass species. In: Aerts, R., Heil, G.W (Eds.), Heathlands: Patterns and Processes in a Changing Environment. Kluwer Academic Publishers, Netherlands, pp. 181-200.

Helsper, H.P.G., Klerken, G.A.M., 1984. Germination of Calluna vulgaris (L.) Hull in vitro under different $\mathrm{pH}$ conditions. Acta Botanica Neerlandica 33, 347-353.

Hester, A.J., Gimingham, C.H., Miles, J., 1991. Succession from heather moorland to birch woodland. III. Seed availability, germination and early growth. J. Ecol. 79, 329-344.

Hill, M.O., 1984. Correspondence analysis: a neglected multivariate method. Appl. Stat. 23, 340-354.

Hobbs, R.J., Curral, J.E.P., Gimingham, C.H., 1984. The use of thermocolour pyrometers in the study of heath fire behaviour. J. Ecol. 72, 241-250.

I.T.G.E., 1995. Atlas del Medio Natural de la Provincia de León, Ministerio de Industria y Energía, Madrid. .

Kruger, F.J., 1984. Effects of fire on vegetation structure and dynamics. In: Booysen, P., Tainton, N.M (Eds.), Ecological Effects of Fire in South African Ecosystems, Ecological Studies, 48. Springer-Verlag, Berlin, pp. $220-243$.

Luis, E., Tárrega, R., Calvo, L., 1989. Biomass and biomass regeneration after disturbance in shrub communities in León province (NW Spain). In: Grassi, G., Gosse, G., Dos Santos, G (Eds.), Biomass for Energy and Industry, Fifth European Conference, Elsevier Applied Science, London. pp. 1114-1120.

Mallik, A.U., 1986. Near-ground micro-climate of burned and unburned Calluna heathland. J. Environ. Manag. 23, 157-171.

Mallik, A.U., Gimingham, C.H., 1983. Regeneration of heathland plants following burning. Vegetatio $53,45-58$.

Mallik, A.U., Gimingham, C.H., 1985. Ecological effects of heather burning II. Effects on seed germination and vegetative regeneration. J. Ecol. 73, 633-644.

Marcos, E., Luis, E., Tárrega, R., 1998. Chemical soil changes in a shrubland after experimental fire. In: Trabaud, L (Ed.), Fire Management and Landscape Ecology. International Association of Wildland Fire, Fairfield, USA, pp. 3-12.

Margalef, R., 1972. Ecología marina. Dossat, Barcelona.

Pielou, E.C., 1969. An Introduction to Mathematical Ecology. Wiley, New York.

Pons, T.L., 1989. Dormancy and germination of Calluna vulgaris (L.) Hull and Erica tetralix L. seeds. Acta Oecolog. 10, 35-43.

Power, S.A., 1998. Impacts and fate of experimentally enhanced nitrogen deposition on a British lowland heath. In: Kaland, P.E., Skogen, A (Eds.), Sixth European Heathland Workshop, Bergen, Norway.

Rívas Martínez, S., Gandullo, J.M., Allué, J.L., Montero, J.L., González, J.L., 1987. Memoria del mapa de series de vegetación de España. ICONA, Madrid. Spain.

Rode, M.W., 1999. Influence of forest growth on former heathland on nutrient input and its consequences for nutrition and management of heath on forest. For. Ecol. Manag. 114, 31-43.

Roquero, C., Porta, J., 1998. Agenda de Campo para estudio del suelo. Universidad Politécnica de Madrid, E.T.S. Ing. Agrónomos, Madrid.

Shannon, C.E., Weaver, W., 1949. The Mathematical Theory of Communication. University of Illinois Press, Urbana. 
Strandberg, M., Johansson, M., 1999. Uptake of nutrients in Calluna vulgaris seed plants grown with and without mycorrhiza. For. Ecol. Manag. 114, 129-135.

Ter Braak, C.J.F., 1991. CANOCO (Versión 3.12), A FORTRAN program for canonical community ordination by partial/detrended/ canonical/correspondence analysis, principal component analysis and redundancy analysis, TNO, Wageningen. .

Tukey, J.W., 1949. Comparing individual means in the analysis of variance. Biometrics 5, 99-114.

Tutin, T.G., Heywood, V.H., Burges, D.H., Valentine, D.H., Moore, D.M., Walters, S.M., Webb, D.A., 1964-1980. Flora Europea. Cambridge University Press, Cambridge.
Valbuena, M.L., Tárrega, R., Luis-Calabuig, E., 2000. Seed banks of Erica australis and Calluna vulgaris in a heathland subjected to experimental fire. J. Veg. Sci. 11, 161-166.

Vera, M.L., Obeso, J.R., 1995. Regeneración del brezal atlántico de Cabo de Peñas después de un incendio severo. Studia Oecolog. 12, 223-236.

Watt, A.S., 1947. Pattern and process in the plant community. J. Ecol. 35, $1-22$.

Webb, N.R., 1998. The traditional management of European heathlands. J. Appl. Ecol. 35, 987-990.

Yesmin, L., Gammack, S.M., Cresser, M.S., 1996. Effects of atmospheric nitrogen deposition on ericoid mycorrhizal infection of Calluna vulgaris growing in peat soils. Appl. Soil Ecol. 4, 49-60. 